\title{
LEADERSHIP BALANCE: IKLIM KOMUNIKASI ORGANISASI PEKERJA MILENIAL DAN CUSTOMER DALAM HOSPITALITY INDUSTRY
}

\author{
Dewi Febrina Iriani \\ Corporate Communication, London School of Public Relations, dfebrinairiany@gmail.com
}

\begin{abstract}
ABSTRAK
Hospitality Industry merupakan salah satu industri yang berpengaruh dalam mendukung pertumbuhan ekonomi di Indonesia, salah satunya industri kuliner. Berjamurnya industri kuliner tentunya membutuhkan sumber daya manusia yang cukup banyak, seiringan dengan hal tersebut pekerja muda atau generasi milenial saat ini tengah berada di usia yang produktif. Namun, faktanya ditengah perkembangan industri kuliner ini, pemimpin mengalami beberapa kesulitan yang salah satunya adalah mengimbangi tuntutan pelanggan di era globalisasi ini yang cukup kritis terhadap suatu produk atau jasa yang akan mereka gunakan, dibarengi oleh pekerja milenials yang cenderung sulit diatur. Pembahasan penelitian ini adalah bagaimana pemimpin dalam industri kuliner menyikapi fenomena ini, serta gaya kepemimpinan yang tepat untuk situasi ini.

Hospitality Industry is one of the influential industries to support economic growth in Indonesia, the culinary industry is one of it. The incraseing number of culinary industries certainly requires considerable human resources, along with that situation, young workers or millenial generation is currently in a productive age. However, in fact, amid the development of this culinary industry, the leader experienced some difficulties, one of them is to balance the demands of customers in this era of globalization that critical enough for a product or service that they will use, along with millenials workers who tend to be difficult to regulate. The discussion of this research is how leaders in the culinary industry address this phenomenon, as well as the appropriate leadership style for this situation.
\end{abstract}

Keywords : Hospitality Industry, Leadership, Millenials, Culture Organization, Climate Organization

\section{Pendahuluan}

Dalam kehidupan sehari-hari manusia banyak menghabiskan waktu dengan berorganisasi, karena pada dasarnya manusia merupakan makhluk sosial.Organisasi memiliki peran yang cukup penting dalam bersosialisasi.Oleh karena itu penting untuk berorganisasi sejak dini, mulai dari keluarga, lingkungan sekitar, sekolah, hingga tempat kerja. James G. March (2006, p. 23 - p. 25) menjelaskan dalam kehidupan bermasyarakat, organisasi merupakan sekelompok orang dalam himpunan di masyarakat yang memiliki suatu hal yang sama sebagai sistem kordinasi. Sementara di dalam perusahaan, Ralp Currier Davis juga mengemukakan pendapatnya bahwa organisasi terbentuk dari sekelompok orang yang bertujuan sama dibawah sebuah kepemimpinan.

Organisasi perusahaan merupakan wadah yang berfungsi untuk bertukar informasi dan pengembangan kualitas diri.Sebuah organisasi dianggap berhasil ketika para anggota satu dengan yang lainnya saling terikat dalam satu kesatuan dengan tujuan untuk mengembangkan potensi diri demi tercapainya tujuan bersama.Hal tersebut juga 


\section{National Conference of Creative Industry: \\ Sustainable Tourism Industry for Economic Development}

Universitas Bunda Mulia, Jakarta, 5-6 September 2018

ISSN No: 2622-7436

didukung oleh hadirnya budaya organisasi ditengah-tengah perusahaan.Berdasarkan penelitian yang dilakukan oleh Kotter dan Heskerr ditemukan bahwa budaya organisasi dapat memengaruhi faktor kinerja ekonomi dalam jangka waktu yang panjang.Selain itu, Foster (1999) juga mengutarakan bahwa lingkungan kerja yang baik dapat menciptakan kinerja anggota yang memiliki produktivitas yang tinggi.

Budaya kerja sangat berhubungan dengan budaya organisasi. Menurut Robin dan Judge perilaku anggota pada tiap-tiap organisasi sangat dipengaruhi oleh budaya kerja yang kuat (Zulkifli, 2014). Oleh karena itu, budaya yang kuat dapat menciptakan keharmonisan serta rasa saling menghormati diantara para anggotanya. Akan tetapi, apabila di dalam organisasi ditanamkan budaya yang mengarah pada sikap-sikap atau pola kerja yang negatif, maka akan mempengaruhi perilaku serta perkembangan organisasi di masa yang akan mendatang.

Seiring berkembangnya zaman, adanya budaya organisasi dalam struktur sebuah perusahaan adalah hal yang utama, karena melalui budaya organisasi yang baik di dalam internal perusahaan akan menghasilkan anggota-anggota organisasi yang baik pula. Diketahui, saat ini anggota organisasi berperan cukup penting dalam struktur perusahaan.Di dalam budaya organisasi, terdapat iklim komunikasi organisasi.

Katz dan Kahn (Romli, 2011) menjelaskan bahwa iklim komunikasi organisasi terdapat arus informasi, pertukaran serta pemindahan arti pada konteks komunikasi di dalam suatu organisasi. Iklim komunikasi organisasi Dalam dunia pekerjaan umum ditemukan adanya gap antara generasi sebelumnya dengan generasi milenial yang mengakibatkan generasi milenial sulit untuk beradaptasi di lingkungan pekerjaan.

Menurut Taguiri (1968, p. 27) iklim merupakan suatu kualitas dalam lingkungan internal yang memiliki satu kesatuan yang terikat. Iklim organisasi memiliki beberapa tahap, yakni pertama: dialami oleh anggota organisasi, kedua: iklim memengaruhi perilaku diri anggota tersebut, lalu yang terakhir menjelaskan mengenai nilai-nilai karakteristik yang ada dalam lingkungan organisasi tersebut. Iklim organisasi menjadi dorongan terhadap kinerja pekerja agar dapat terus bertukar informasi pada sesama anggota untuk meningkatkan potensi diri.

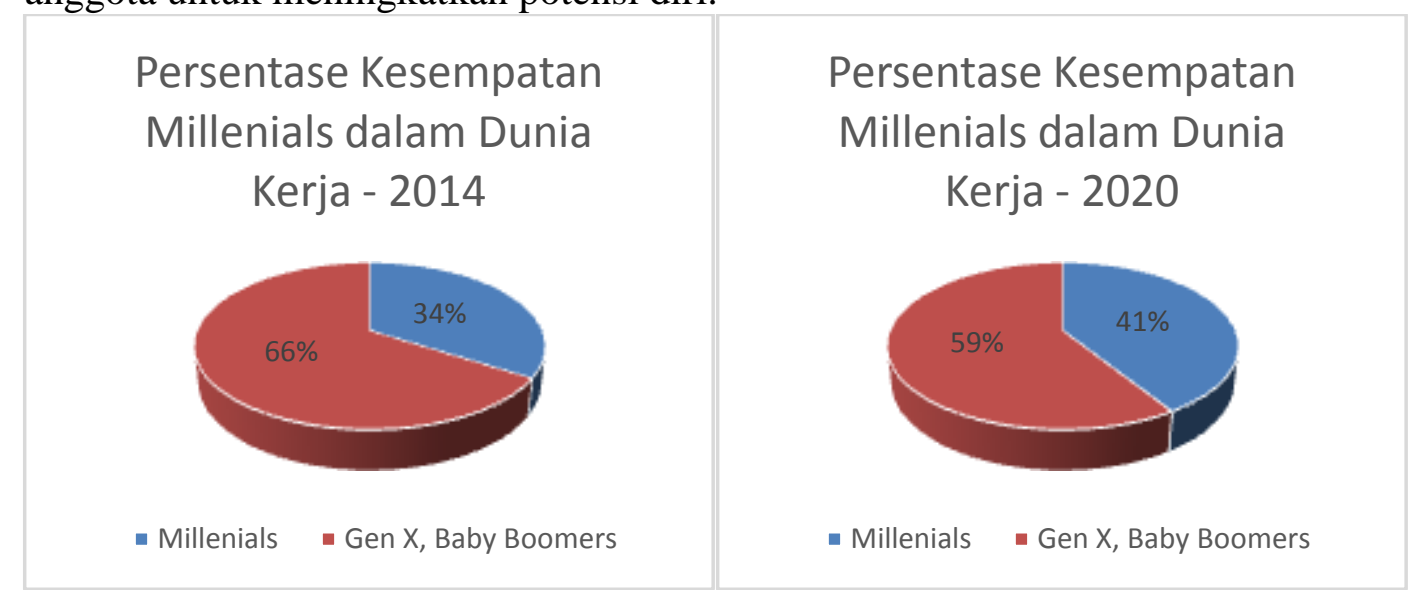

Berdasarkan tabel di atas, Lynch (2008) mengungkapkan bahwa kesempatan bekerja untuk generasi milenial meningkat dari 34\% di tahun 2014 menjadi $41 \%$ di tahun 2020. Pada tahun 2020 generasi milenial memasuki usia produktif dan menjadi penyumbang tenaga kerja yang cukup signifikan..Munculnya perbedaan generasi yang muncul di tengah masyarakat saat ini menimbulkan konflik tersendiri dalam kelompok masyarakat tersebut. Kupperschmidt's dalam penelitiannya (2000) mengatakan bahwa generasi merupakan sebuah kelompok individu yang mengidentifikasikan kelompok 


\section{National Conference of Creative Industry: \\ Sustainable Tourism Industry for Economic Development}

Universitas Bunda Mulia, Jakarta, 5-6 September 2018

ISSN No: 2622-7436

berdasarkan kesamaan tahun kelahiran, usia, lokasi tempat tinggal, serta kejadiankejadian dalam kehidupan di secara signifikan berpengaruh kepada kelompok individu tersebut.

\begin{tabular}{lcccc}
$\begin{array}{c}\text { Karakteristik } \\
\text { Demografi }\end{array}$ & $<\mathbf{1 6}$ tahun & $\begin{array}{c}\mathbf{1 6 - 3 0} \\
\text { tahun }\end{array}$ & $>\mathbf{3 0 \text { tahun }}$ & Total \\
\hline $\begin{array}{l}\text { Total } \\
\text { Tipe Daerah }\end{array}$ & 28,81 & 24,27 & 46,92 & 100,00 \\
$\quad$ Perkotaan & 27,92 & 25,22 & 46,87 & 100,00 \\
$\quad \begin{array}{l}\text { Perdesaan } \\
\text { Jenis Kelamin }\end{array}$ & 29,82 & 23,19 & 46,98 & 100,00 \\
Laki-laki & 29,37 & 24,43 & 46,20 & 100,00 \\
Perempuan & 28,25 & 24,10 & 47,65 & 100,00
\end{tabular}

Menurut tabel di atas, Indonesia memiliki jumlah total pemuda sebanyak 63,36 juta jiwa, 24,27\% diantaranya ada pada usia yang produktif. Melalui data tersebut, dapat terlihat bahwa kehadiran Milenial dalam dunia kerja ada di angka yang cukup signifikan, sebanyak 51,47\% pemuda yang bekerja.

Seiring dengan berjalannya waktu, tentunya tingkat pekerja milenial dalam usia yang produktif akan bertambah setiap tahunnya. Pada tahun 2017 tercatat sektor industri perdagangan, kuliner dan akomodasi merupakan industri yang paling banyak mempekerjakan milenial hingga mencapai seperempat $(25,57 \%)$ dari total pemuda Indonesia dalam usia bekerja. Pada kota-kota besar, industri kreatif ini menyerap pemuda bekerja sekitar $32,15 \%$. Hal tesebut berkesinambungan dengan para pelaku industri yang melihat bahwa generasi milenial berpotensi besar dalam sektor perekonomian negara.Industri kreatif di Indonesia menangani 16 subsektor.

Peran industri makanan dan minuman saat ini menjadi salah satu tren yang menjadi tujuan utama para wisatawan dalam travelling. Fenomena tersebut terjadi karena keunikan makanan dapat membuat para wisatawan domestic atau mancanegara kembali untuk menikmati makanan yang sama. Termasuk di Indonesia, negara yang kaya akan cita rasa dalam industri kuliner, diyakini seringkali membuat wisatawan kembali mengunjungi Indonesia. Oleh karena itu takhayal apabila indstri kuliner juga membantu perekonomian di Indonesia.

Industri makanan dan minuman (hospitality industry) merupakan salah satu industri kreatif yang menjadi penyongkong pertumbuhan manifaktur dan ekonomi di Indonesia. Berdasarkan catatan Kementrian Penindustrian, industri makanan dan minuman berkontribusi kepada Produk Domestik Bruto (PDB) industri non migas hingga 34,95\% pada triwulan III tahun 2017. Angka ini naik sebanyak 4\% dari tahun sebelumnya pada periode yang sama. (Kemenperin, 2017).Oleh karena itu, industri makanan dan minuman di Indonesia kian meningkat setiap tahunnya. Fenomena ini menjadikan Indonesia menjadi target

Perkembangan Industri Kreatif di Indonesia sangat besar.Hal tersebut berdampak positif pada Ekonomi Kreatif Indonesia.Ekonomi Kreatif Indonesia yang berada dibawah pengawasan Badan Ekonomi Kreatif (BEKRAF). Badan Ekonomi Kreatif merupakan sebuah Lembaga Pemerintah Non Kementerian yang bertanggung jawab di bidang ekonomi kreatif dengan enam belas subsector. Maka dari itu, tak ayal apabila pelaku bisnis dalam bidang ini beragam, mulai dari generasi tua, muda, laki-laki atau perempuan, yang berasal dari dalam hingga luar negeri pun ikut mencoba bisnis ini 


\section{National Conference of Creative Industry: \\ Sustainable Tourism Industry for Economic Development}

Universitas Bunda Mulia, Jakarta, 5-6 September 2018

ISSN No: 2622-7436

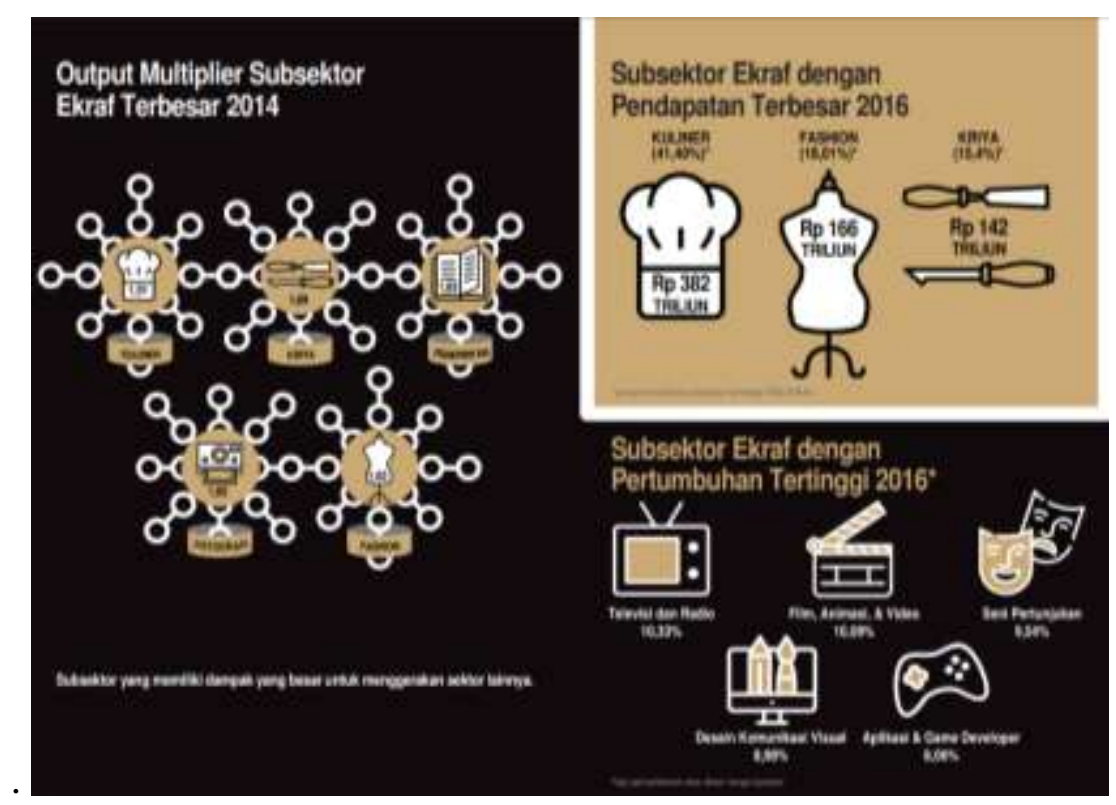

Kesuksesan hospitality industry, khususnya bisnis kuliner pada kota-kota besar di Indonesia, menjadikan sektor bisnis ini sangat diminati.Bisnis kuliner merupakan salah satu subsektor ekonomi kreatif yang memiliki pendapatan terbesar setiap tahunnya, diikuti dengan Fashion dan Kriya. Bisnis kuliner merupakan salah satu sub sektor yang menjanjikan, terlebih lagi di kota-kota besar seperti Jakarta.

Jakarta dikenal sebagai kota metropolitan. Gaya hidup masyarakat di kota Jakarta dikenal modern, familiar dengan segala macam kecanggihan teknologi, kepraktisan, dan suka bersosialisasi. Meningkatnya bisnis kuliner dipicu oleh pola kehidupan masyarakat yang sibuk, tidak memiliki waktu untuk membuat makanan, serta gemar berkumpul menjadikan bisnis kuliner sangat mewabah di kota Jakarta, termasuk dengan bisnis kedai atau warung kopi (café).

Penduduk 15 Tahun Ke Atas yang Bekerja menurut Lapangan Pekerjaan Utama 2013 - 2017

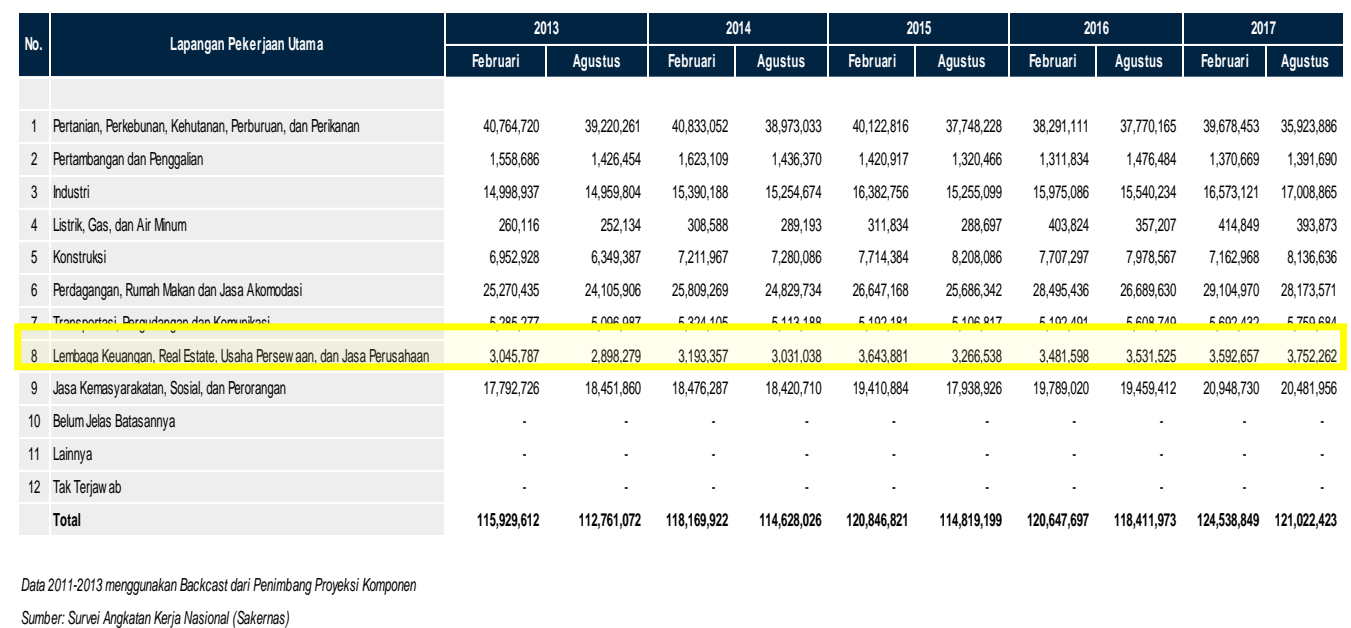

Berdasarkan Survei Angkatan Kerja Nasional atau Sakernas diketahui bahwa angka pekerja tertinggi di Indonesia berada pada sektor Perdagangan, Rumah Makan dan Jasa Akomodasi.Hal tersebut berturut-turut sejak 5 tahun terakhir.Kenaikan angka pekerja terlihat sangat signifikan setiap tahunnya, maka dari itu sektor bisnis perdagangan, jasa serta rumah makan atau kuliner sangat menjamur di Indonesia. 


\section{National Conference of Creative Industry: \\ Sustainable Tourism Industry for Economic Development}

Universitas Bunda Mulia, Jakarta, 5-6 September 2018

ISSN No: 2622-7436

Di dalam konteks hospitality industry, kinerja yang utama mencakup segala aktivitas yang terlihat dari depan atau disebut front-of-the-house activity. Selain itu, kinerja kedua yakni melakukan segala aktivitas pendukung untuk segala kegiatan yang dilakukan pada front-of-the-house activity atau bisa disebut back-of-the-house activity (Motowidlo, 1997), seperti team building, budaya organisasi serta gaya kepemimpinan, dan segala bentuk aktivitas lainnya yang digunakan untuk menunjang profesionalitas dalam bekerja di hospitality industry.

Sejatinya yang terjadi sekarang ini, dengan maraknya industri kuliner yang banyak mempekerjakan generasi muda mempengaruhi model kepemimpinan yang dijalankan dalam sebuah organisasi.Kedai Kopi XYZ merupakan salah satu kedai kopi dengan jumlah pekerja milenial lebih banyak dibandingkan dengan Gen $X$ atau Baby Boomers. Kehadiran milenial bukan hanya berdampak positif bagi perusahaan namun juga imej negatif milenial seperti tingginya self esteem atau dikenal dengan harga diri, membuat Millenials juga memiliki karakteristik yang kesensitifan emosi yang cukup tinggi (Twenge \& Campbell, 2003), sehingga dapat dikatakan bahwa Millenial masih memiliki sikap pribadi antisocial dalam bekerja maupun kehidupan pribadi mereka (Janice A. Black,dkk, 2013).

Menurut Tjiptono (2007) menyebutkan bahwa kepuasan pelanggan didasari oleh pelayanan yang tepat sesuai dengan kebutuhan dan harapan konsumen.Hal tersbeut menjadi tantangan tersendiri untuk pelaku bisnis kuliner, khususnya Kedai Kopi XYZ yang kebanyakan pekerjanya adalah generasi milenial.Dalam kondis ini, pemimpin berperan penting untuk membentuk suasana kerja yang positif, sehingga menciptakan keseimbangan antara pelanggan yang meningkat dan pelayanan yang baik.

Berdasarkan fenomena yang dibahas sebelumnya, peneliti tertarik untuk mengkaji studi deskriptif gaya kepemimpinan store manager dalam membangun keseimbangan antara perubahan iklim organisasi pekerja milenial dan adanya tuntutan pelanggan di Kedai Kopi XYZ. Dan hasil dari penelitian ini diharapkan dapat terlihat pentingnya peran pemimpin dalam menghadapi perubahan iklim komunikasi organisasi pekerja milenial pada suatu perusahaan.

\section{Metode Penelitian}

Jenis Penelitian

Penelitian yang digunakan dalam penelitian ini adalah Metode Penelitian Deskriptif Kualitatif. Dalam Moleong (2009) Bogdan dan Taylor menjelaskan bahwa teknik pengolahan data dalam penelitian deskriptif kualitatif terdiri dari kata-kata tertulis atau lisan dan teori perilaku yang diminati oleh beberapa fenomena yang akan diangkat dalam pembahasan ini. Hasil dari penelitian ini berasal dari wawancara secara mendalam dengan narasumber lalu mengkontruksikan kedalam teori yang akan digunakan dalam penelitian, sehingga mendapatkan gambar jelas mengenai topic yang dibahas.

\subsection{Budaya Organisasi}

Budaya organisasi memiliki pengertian yang luas. Beberapa ahli mengatakan bahwa budaya organisasi berhubungan erat dengan corporate communication, dimana secara singkat peran dan definisinya hampir sama, yaitu sebagai pedoman etika karyawan saat bekerja dan juga berorientasi dalam perusahaan. Budaya organisasi juga berperan sebagai landasan perusahan.Oleh karena itu, setiap perusahaan perlu memiliki landasan 


\section{National Conference of Creative Industry: \\ Sustainable Tourism Industry for Economic Development}

Universitas Bunda Mulia, Jakarta, 5-6 September 2018

ISSN No: 2622-7436

yang baik atau budaya organisasi yang baik agar menghasilkan karyawan dengan kinerja dan potensi yang baik.

Melalui budaya organisasi, karyawan diarahkan oleh perusahaan untuk menganut pemahaman-pemahaman yang diterapkan perusahan, dengan tujuan untuk mencapai visi dan misi perusahaan. Kotter dan Heskett (1992) menyatakan bahwa di dalam budaya organisasi terdapat pemahaman yang sama diantara para anggota organisasi.

\subsection{Komunikasi Organisasi}

Komunikasi organisasi berperan penting dalam kehidupan sehari-hari. Menurut Brent \& Lea (2006, p. 296) dalam komunikasi organisasi terdapat lima fungsi utama, yaitu: menentukan tujuan, menjelaskan peran dan tanggung jawab anggota di dalam organisasi, mengkordinasi, membangun jaringan informasi dan mengembangkan budaya dan iklim dari perusahaan atau organisasi.

Adanya hubungan baik antara anggota organisasi juga menghasilkan iklim yang baik.Iklim organisasi yang baik menularkan energy positif kepada para anggota organisasi; semangat kerja dan produktifitas kerja.Iklim komunikasi organisasi menjadi penting karena merupakan wujud dari organisasi di dalamnya. Ketika organisasi didalamnya berjalan dengan baik, maka iklim komunikasi yang dihasilkan akan terlihat positif, begitu pula sebaliknya. Positif dan negative-nya sebuah iklim komunikasi organisasi menurut Brent and Lea (2006, p. 317) dibentuk oleh karakter-karakter berikut;

1. Dukungan dalam berkomunikasi oleh pemimpin organisasi

2. Persepsi kualitas dan akurasi dalam berkomunikasi ke bawahan

3. Keterbukaan dalam berkomunikasi antara organisasi

4. Peluang untuk mempengaruhi yang besar dalam konteks komunikasi atasan ke bawahan

5. Presepsi komunikasi yang bisa diandalakn dari bawahan ke atasan

Pada konteks iklim komunikasi organisasi, iklim yang positif dan tingginya kepuasan pekerja mencerminkan pelayanan yang baik kepada klien dan pelanggan, begitu juga rekan kerja

\subsection{Gaya Kepemimpinan}

Gaya kepemimpian (leadership styles) adalah model atau cara pimpinan organisasi dalam mengatur organisasi atau kelompok yang ada dibawah pimpinan mereka, dengan tujuan untuk mencapai visi dan misi perusahaan. Gaya kepemimpinan pada organisasi berbeda-beda tergatung bagaimana pemimpin mereka, dalam Brent \& Lea (2006, p. 284) teori gaya kepemimpinan terbagi menjadi tiga, yaitu;

1. Teori Kepemimpian merupakan Genetik

Teori ini berasumsi bahwa kualitas dari seorang pemimpin melekat pada kepribadian pemimpin itu sendiri, "good leader are born not made". Teori ini dipercaya bahwa seorang pemimpin adalah anugrah yang sudah ditetapkan sejak mereka lahir ke dunia.

2. Teori Gaya Kepemimpinan Terbaik

Teori ini dipercaya bahwa gaya kepemimpinan seorang pemimpin harus menyesuaikan dengan bawahnnya dalam organisasi. Anggota dalam organisasi atau perusahaan dianggap penting untuk mencapai tujuan perusahaan.

3. Teori Gaya Kepemimpinan yang Kontekstual

Konsep dari teori ini adalah penggabungan antara kedua teori sebelumnya, yaitu kepemimpinan adalah hasil dari kemampuan individu dan juga terdapat warisan atau sisi genetik seorang pemimpin. 


\section{National Conference of Creative Industry: \\ Sustainable Tourism Industry for Economic Development}

Universitas Bunda Mulia, Jakarta, 5-6 September 2018

ISSN No: 2622-7436

Fleishman dan Peters (1962) mengemukakan bahwa gaya kepemimpinan adalah bentuk pola konsistensi seorang pemimpin pada saat mempengaruhi orang lain atau bawahnnya di perusahaan atau organisasi.

Gaya kepemipinan yang dilakukan oleh seorang pemimpin dalam organisasi sangat berpengaruh sebagai output yang dihasilkan oleh organisasi itu sendiri. Dalam arti, gaya kepemimpinan berperan sangat penting dalam suatu perusahaan yang berdampak secara langsung kepada kinerja perusahaan.

\subsection{Gaya Kepemimpinan di dalam Budaya Organisasi}

Budaya Organisasi memiliki banyak arti dan konsep pemahamannya menurut para ahli, menurut Brahmasari (2004, p.16) mengatakan bahwa arti dari konsep budaya organisasi atau bagaimana budaya organisasi harus diobservasi dan diukur, hal tersebut dikarenakan adanya ketidak pahaman mengenai formulasi teori budaya organisasi, gambaran organisasi dan kemungkinan hubungannya dengan dampak kinerja karyawan dalam sebuah perusahaan.

Peran kepemimpinan dalam organisasi atau perusahan terbagi menjadi tiga bentuk menurut Siagian (2002, p.66) yaitu:

1) Peran kepemimpinan yang bersifat interpersonal

Seorang pemimpin dalam perusahaan atau organisasi merupakan simbol akan keberadaan organisasi, seorang pemimpin bertanggung jawab untuk memotivasi dan memberikan arahan kepada bawahan, dan seorang pemimpin mempunyai peran sebagai penghubung.

2) Peran kepemimpinan yang bersifat informasional

Seorang pemimpin dalam organisasi mempunyai peran sebagai pemberi, penerima dan penganalisa informasi.

3) Peran kepemimpinan dalam pengambilan keputusan.

Seorang pemimpin sebagai penentu kebijakan yang akan diambil berupa strategi-strategi bisnis yang mampu untuk mengembangkan inovasi, mengambil peluang atau kesempatan dan bernegosiasi dan menjalankan usaha dengan konsisten.

\section{Hasil dan Pembahasan}

Generasi Milenial menurut Campbell (2005) merupakan generasi yang memiliki sikap narsisme. Memiliki sikap narsis merupakan hal yang positif, namun sikap tersebut dapat menjadi negatif ketika mereka merasakan over-confident atas dirinya, sehingga pekerja muda kurang memiliki rasa empati antar sesama pekerja dan tidak bisa menerima prespektif orang lain. Milenial memiliki karakter mudah menyalahkan orang lain, merasa beruntung jika sesuatu berjalan dengan tidak seharusnya, serta kecenderungan untuk melepaskan tanggung jawab dalam sebuah kegagalan juga lekat dengan karakteristik Milenial (Jean M. Twange, 2008). Generasi Milenial juga dikenal sebagai generasi yang memiliki sikap individual yang tinggi, self-esteem serta sikap acuh dengan peraturan sosial ataupun etika sosial dalam dunia kerja (Twenge, 2008).

Milenial ke atas disebut sebagai generasi yang paling dicari oleh perusahaanperusahaanbesar hingga start up. Hal tersebut yang menyebabkan beberapa perusahaan melakukan restrukturisasi karyawan lama; Generasi Baby Boomers \& Generasi X dengan para pekerja muda atau Millenials dalam organisasinya untuk mengikuti perkembangan zaman. Persaingan antara generasi ini menciptakan gap atau kesenjangan antara karyawan. Perbedaan atau keragaman tujuan yang diinginkan oleh tiap-tiap generasi tersebut cenderung menimbulkan sikap yang kurang memahami prespektif 


\section{National Conference of Creative Industry: \\ Sustainable Tourism Industry for Economic Development}

Universitas Bunda Mulia, Jakarta, 5-6 September 2018

ISSN No: 2622-7436

orang lain, membingungkan rekan sesama team sehingga dapat menciptakan rasa frustasi dan stress yang tinggi antar karyawannya, khususnya dalam hospitality industry.

Pada hospitality industry, Millenials dituntut bekerja dalam team, untuk mendukung satu sama lain demi menghindari tingginya angka stress dalam menghadapi customers. Beberapa Millenials kebanyakan memiliki pribadi yang unik, menyenangkan serta mudah bersosialisasi dan beradaptasi dengan lingkungan yang baru.

Fenomena Generasi Milenials di hospitality industry khususnya sektor kuliner menjadi sorotan management perusahaan. Banyak komplain pelanggan yang masuk ke support center, salah satunya mengenai tata cara pelayanan yang tidak sopan, tidak ramah serta tidak sesuai SOP menjadi evaluasi untuk pemimpin di Kedai Kopi XYZ.

Pemimpin Kedai Kopi XYZ menilai bahwa permasalahan yang terjadi berasal dari kegagalan dalam membangun komunikasi internal, sehingga para pekerja milenial tidak memahami prosedur kerja yang sesungguhnya.Untuk itu, iklim komunikasi organisasi harus dibangun dengan energi positif agar para pekerja milenial memahami standar pekerjaan di industri ini.

Iklim organisasi pada suatu perusahaan atau organisasi sebagian besar merupakan ketentuan pemimpin.Gaya kepemimpinan menurut Hasibuan (2007, p. 170) bahwa pemimpin terbagi menjadi tiga bagian, yaitu otoriter, partisipatif dan delagatif. Dalam situasi dan kondisi tertentu, pemimpin memiliki gaya dan karakter yang berbeda. Gaya kepemimpinan otoriter cenderung mengarahkan semua kekuasaan secara mutlak hanya kewenangan pimpinan kelompok, tidak mengikut sertakan bawahan dalam pengambilan keputusan atau problem solving. Sementara gaya kepemimpinan partisipatif yaitu teknik memimpin dengan cara persuasive, memberikan kenyamanan kepada bawahan agar tercipta loyalitas, memotivasi karyawan secara bijaksana untuk bekerja lebih baik dan maksimal tanpa memberikan beban kepada bawahan tersebut.

Terakhir, gaya kepemimpinan delegatif. Pada era globalisasi saat ini, gaya kepemimpinan ini kerap terlihat di beberapa sub sektor industri, termasuk industri kuliner.

Gaya kepemimpinan yang diterapkan pada Kedai Kopi XYZ adalah gaya kepemimpinan yang ke arah delegatif, mengimbangi para pekerja muda yang tidak bisa dipimpin dengan cara otoriter. Ditambah dengan kondisi saat ini, dimana pelanggan dan pekerja muda memiliki posisi yang penting di dalam bisnis kuliner.Pelanggan saat ini cederung mudah untuk melakukan perpindahan merek (brand switching).Kondisi ini terjadi karena keinginan pelanggan untuk adanya variasi atau keberagaman merek (variety seeking) dalam produk yang dijual (Abisatya, 2009), tak hayal apabila persaingan yang ketat antara bisnis kuliner memaksakan para pemain dalam bisnis ini menonjolkan keunikan dari bisnis mereka, mulai dari variasi minuman dan makanan, fasilitas yang lengkap dengan akses internet yang cepat, serta design yang menarik.Fenomena ini menimbulkan bahwa sektor industri kuliner tidak hanya fokus terhadap pelayanan namun juga faktor-faktor yang telah disebutkan. Pelanggan saat ini lebih kritis dan hati-hati terhadap produk atau jasa apa yang akan mereka beli atau gunakan. Oleh karena itu, pada sektor industri terutama bisnis minuman, Kedai Kopi XYZ tidak hanya fokus terhadap kualitas produk mereka namun juga jasa yang diberikan kepada pelanggan, dimana kepuasan pelanggan tidak hanya tentang produk namun juga jasa yang telah mereka terima.Kepuasan pelanggan menyangkut persaan mengenai nilai perbandingan produk yang telah mereka terima atau dapatkan (Kotler, 2001). 


\section{National Conference of Creative Industry: \\ Sustainable Tourism Industry for Economic Development}

Universitas Bunda Mulia, Jakarta, 5-6 September 2018

ISSN No: 2622-7436

\section{Simpulan}

Model kepemimpinan yang santai namun tetep tegas dianggap sesuai dengan karakter pekerja muda saat ini.Diketahui, generasi milenial cenderung mudah untuk keluar dan masuk perusahaan.Oleh karena itu, sebagai peran pemimpin adalah menciptakan iklim komunikasi yang positif sehingga dapat membentuk karakter pekerja milenial yang baik.Hal tersebut berkesinambungan dengan customer para era globalisasi yang cenderung sering komplain dan kritis.Pemimpin juga harus melihat kondisi dan situasi yang terjadi, tidak mudah untuk menyalahkan bawahannya.

\section{Daftar Pustaka}

Ambler, Tim and friends. 2002. Relating Brand and Customer Prespectives on Marketing Management. Journal of Services Research, London Business School. Bastian, Denny.Analisa Pengaruh Citra Merek (Brand Image) dan Kepecayaan Merek (Brand Trust) Terhadap Loyalitas Merek (Brand Loyalty) ADES PT. Ades Alfindo Putera Setia.

Fahmi, Syaifuddin. 2016. Pengaruh Stress Kerja dan Konflik Kerja Tehadap Semangat Kerja Karyawan Pada PT. OMEGA Mas Pasuruan.

Gollup, Gordon G. and friends. 2010. The Science of Sex Appeal: An Evolutionary Prespective. Journal of American Psychological, State University of New York. Kotler, Phillips. 2009. Manajemen Pemasaran.Jakarta : Erlangga.

Melliana S, Anastasia. 2006. Menjelajah Tubuh: Perempuan dan MItos Kecantikan. Yogyakarta : LKiS

Munandar, M. Soelaeman. 2000. Ilmu Budaya Dasar. Bandung : PT. Refika Aditama Ponomaren, Polina. 2016. Victoria's Secret : A Case Study of Maintaining Brand. Catolica Lisbon University.

Samuel, Natalia. 2013. Pegaruh Etika Kerja Karyawan Terhadap Kepuasan Konsumen. Sugiyono. 2009. Metode Penelitian Bisnis (Pendekatan Kuantitatif, Kualitatif dan $R \& D)$. Bandung : Alfabeta.

Synnott, Anthony. 1993. Tubuh Sosial : Simbolisme, Diri dan Masyarakat. Jogjakarta : Jalasutera.

T, Zulkifli. 2014. Hubungan Budaya Kerja dengan Komitmen Pegawai Negeri Sipil di Lingkungan Rumah Sakit Jiwa Daerah Atma Husada Mahakam. 